\title{
Ewolucja systemów oświatowych i postaw młodzieży wobec edukacji w krajach Europy Środkowo-Wschodniej ${ }^{2}$
}

\begin{abstract}
This paper is an attempt to show the changes in education in selected countries of Central and Eastern Europe. Article indicates the main directions of change in the philosophy of education and their structural implications for the education system, in response to the changing socio-political and dominant global trends while imitating structural solutions and attitudes present in Western societies. The primary source base constitute a public database (eng. The reports of the World Bank, and Education at Glance published by the OECD) as well as statistical analyzes prepared on their basis. The main aim of this article is to attempt to identify significant similarities and differences which the participation of countries undergoing a similar path of development.
\end{abstract}

\section{Keywords:}

education, educational systems, attitudes towards education, (post) communist countries, modernization imitative

1 Krzysztof Wasielewski, Instytut Socjologii, Wydział Humanistyczny, Uniwersytet Mikołaja Kopernika w Toruniu, Polska, kwasielewski@wp.pl.

2 Artykuł został przygotowany w ramach projektu „Młodzież w krajach (post)komunistycznych - potencjał innowacyjny, nowe konteksty, nowe problemy i nowe wyzwania” finansowanego z funduszy NCN (grant Harmonia, No. UM0-2013/08/M/HS6/00430). 


\section{WPROWADZENIE}

Począwszy od XIX wieku i formowania się w zachodnim kręgu kulturowym nowoczesnego, powszechnego systemu oświatowego, znaczenie kształcenia i kwalifikacji nie tylko formalnych systematycznie wzrasta. Związane jest to, po pierwsze, z szybkimi przemianami cywilizacyjnymi, które są wynikiem rozwoju najpierw przemysłu, a później nowoczesnych technologii i ich wpływu na życie jednostek, zwłaszcza w obszarze rynku pracy (zob. Bauman, 1998; Brown, i in. 2008; Castells, 1996). Po drugie, postępującą globalizacją, której najważniejszą konsekwencją wydaje się zacieśnienie relacji pomiędzy społeczeństwami we wszystkich wymiarach (zarówno społecznym, ekonomicznym, jak i politycznym) (Giddens, 2001). Po trzecie wreszcie, z niemal powszechnym przekonaniem, że racjonalność i wiedza (kwalifikacje), których pośrednikiem jest szeroko rozumiana edukacja, są podstawowymi i niezbędnymi składowymi nowoczesnych społeczeństw opartych na wiedzy i merytokratycznych regułach (Becker, 1964; Drucker, 1969). Wszystkie (wspomniane ledwie) zmiany sprawiły, że edukacja i potwierdzane zazwyczaj poprzez stosowny dyplom kwalifikacje stały się elementem kluczowym tak z perspektywy jednostki, której są niezbędne, by mogła odnaleźć się na rynku pracy, jak i społeczeństw czy ich gospodarek, których dobrobyt, dynamika rozwoju oraz konkurencyjność w coraz większym stopniu zaczęły zależeć od wiedzy i kwalifikacji obywateli (Becker, 1964; Behrman, Stacey, 1997; Collins, 1979). Jeśli spojrzymy na ten problem historycznie, możemy zauważyć, że procesy te wpłynęły na zapotrzebowanie na dobrze wykształcone (i wykwalifikowane) kadry, dynamiczny wzrost aspiracji edukacyjnych i zawodowych młodych ludzi, a także na wzrost poziomu wykształcenia ogółu społeczeństw. Jednak wraz z nimi pojawiło się umasowienie kształcenia oraz proces inflacji wartości wykształcenia (zwłaszcza zaś dyplomów wyższych uczelni) (Dore, 1976). To zaś sprzyjało przenoszeniu się nierówności edukacyjnych na kolejne szczeble kształcenia, a w konsekwencji na utrzymanie się dotychczasowych dominujących trendów stratyfikacyjnych (Boudon, 1974; Collins, 1979). Problemem okazała się również niewielka elastyczność systemów oświatowych oraz nieadekwatność oferty edukacyjnej do potrzeb rynku pracy. Nie zmienia to faktu, że edukacja i zdobyte kwalifikacje wciąż stanowią warunek sine qua non jednostkowego sukcesu zarówno w wymiarze osobistym, jak i zawodowym. Co ważniejsze, dzieje się tak pomimo obniżania rangi dyplomu wyższego wykształcenia. Wpływ na to ma między innymi proces wewnętrznego różnicowania się i komplikowania struktur oświatowych, czego jedną z przyczyn jest systematyczny proces wydłużania się cyklu kształcenia formalnego (i zwiększenie znaczenia edukacji nieformalnej i poza-formalnej). Ten zaś jest konsekwencją konieczności 
dostosowywania i podwyższania swoich kwalifikacji do szybko zmieniającego się rynku pracy. Wspomniane powyżej procesy mają właściwie charakter uniwersalny i jak pokazują różne analizy miały lub mają miejsce we wszystkich społeczeństwach, których rozwój związany jest z umownie rozumianym modelem demokracji liberalnej (Antonowicz, 2015; Berryman, 2000; Berulava, 2005; Polyzoi, Fullan, Anchan, 2003). Czy analogiczny kierunek przemian systemów oświatowych miał miejsce w krajach, które rozpoczęły proces transformacji ustrojowej po rozpadzie Związku Radzieckiego? Czy podobne zmiany transformacyjne w różnych krajach pociągnęły analogiczne, podobne zmiany w edukacji i w funkcjach przez nią realizowanych? Wydaje się, że specyfika państw Europy Środkowo-Wschodniej, państw post-komunistycznych wynika jednak z faktu, że na wspomniane procesy mające charakter uniwersalny (globalny) nałożyły się procesy w pewien sposób wyjątkowe - związane z transformacją ustrojową (odchodzeniem od ustroju komunistycznego i gospodarki centralnie planowanej). Można zatem powiedzieć, że pojawiły się po transformacji ustrojowej „nowe reguły gry”, do których przystosować musiał się system edukacyjny i jednostki w nim się znajdujące (Berryman, 2000). Stawiam tutaj tezę o kluczowej roli procesów imitacyjnych, zbieżnych z procesami obecnymi w społeczeństwach zachodnich, w modernizacji systemów kształcenia. Przyjrzyjmy się kierunkom ewolucji systemów oświatowych i społecznych postaw wobec edukacji w wybranych krajach Europy Środkowo-Wschodniej. Przedmiotem analizy są: Bułgaria, Łotwa, Polska, Rosja, Rumunia i Węgry.

\section{REWOLUCJA W FILOZOFII KSZTALCENIA - KU IMITACJI ZACHODNICH WZORCÓW I WARTOŚCI}

Transformacja ustrojowa wyznaczyła nowe kierunki i nowe cele przed systemami oświatowymi krajów postkomunistycznych. Skala, tempo oraz sposób i styl wprowadzanych zmian były i są zależne od specyfiki poszczególnych krajów (m.in. poziomu rozwoju gospodarczego czy stopnia dynamiki zmian ustrojowych). Wiązały się one przede wszystkim z przewartościowaniem zasadniczych idei i poglądów stojących u podstaw społeczeństwa socjalistycznego. Zastąpione one zostały przez liberalizm i demokrację w sferze polityczno-gospodarczej oraz merytokratyzm w sferze wartości pożądanych oraz sposobów ich realizacji (zob. Aslund, 2000; Lewowicki, 2000; Misztal, 2000; Potulicka, 2012). Na proces ten wpływ miało wiele czynników, m.in. odrzucenie przez społeczeństwo poprzedniego ustroju, formowanie się gospodarki liberalnej wraz z licznie powstającymi firmami prywatnymi, popytu na edukację i postrzeganie wykształcenia jako 
wysoko cenionej wartości (Antonowicz, 2015; Berulava, 2005; Kwiek, 2016; Misztal, 2000). Wszystkie te procesy wpłynęły na wzrost wskaźników skolaryzacyjnych. Szczególnie trudne chwile oświata przeżywała w początkowej fazie procesu transformacji (w latach 90.). Wówczas to systemy edukacyjne wielu państw postkomunistycznych uległy niemal zapaści (m.in. w Rosji i Rumunii) w konsekwencji kryzysu gospodarczego, który dotknął wszystkie sfery funkcjonowania transformujących się państw. Szczególnie mocno kryzys w pierwszych latach po rozpadzie bloku wschodniego odczuła Rosja (i byłe kraje satelickie). Z analiz przeprowadzonych przez Marka S. Johnsona (1996) wynika, że sytuacja ta doprowadziła do gwałtownego pogorszenia systemu edukacji publicznej i obsady kadrowej w wielu krajach, które uzyskały niezależność i niepodległość.

Generalnie rzecz ujmując, w przypadku większości krajów Europy Środkowo-Wschodniej wraz z odrzuceniem poprzedniego ustroju i obraniem wyraźnego kierunku zmian (ku demokracji i wolnemu rynkowi) nastąpiła adekwatna do nich korekta polityki oświatowej. Jej podstawowymi cechami wspólnymi były: odrzucenie mocno zideologizowanych programów kształcenia, położenie nacisku na nadrobienie luki edukacyjnej i cywilizacyjnej w odniesieniu do państw zachodnich poprzez podniesienie poziomu wykształcenia ogółu społeczeństwa, szerszy dostęp do edukacji na wszystkich szczeblach kształcenia młodzieży z grup do tej pory marginalizowanych bądź nieuprzywilejowanych, dopuszczenie do funkcjonowania na rynku usług edukacyjnych (zwłaszcza w obrębie szkolnictwa wyższego) podmiotów prywatnych, stopniowe wprowadzanie regulacji wynikających z deklaracji bolońskiej, zmiany w finansowaniu edukacji powszechnej oraz szkolnictwa wyższego (dopuszczenie odpłatności za studia), zmiany w systemie edukacji powszechnej tworzące podstawy do umasowienia studiów wyższych, poprawienie jakości kształcenia oraz wprowadzenie mechanizmów ją monitorujących. Pojawienie się nowych warunków oraz nowych reguł funkcjonowania oświaty przyczyniło się do procesów różnicowania się instytucji pod względem źródeł ich finansowania, jakości kształcenia, pochodzenia społecznego uczniów, a także możliwości kształtowania karier, jakie dawały one swoim uczniom (Berryman, 2000; Hadjar, Becker, 2009; Herbst, Wojciuk, 2014; Karpov, Lisovskaya, 2005).

Wraz z transformacją ustrojową nacisk położono przede wszystkim na pluralizację edukacji i dopuszczenie do funkcjonowania na rynku usług edukacyjnych podmiotów prywatnych oraz autonomię szkolnictwa wyższego (m.in. w Bułgarii, Polsce od 1990, w Rumunii od 1991 roku, w Rosji od 1992 roku). Równolegle w tych krajach wprowadzano regulacje dotyczące prawa do bezpłatnej edukacji na wszystkich poziomach - zazwyczaj jako zapis konstytucyjny (m.in. Polska, Rumunia), prawa do edukacji w językach mniejszości (m.in. Polska, Rumunia, Węgry) 
oraz nieco później zmiany w zarządzaniu i finansowaniu oświaty (m.in. Bułgaria, Łotwa, Polska, Rosja, Rumunia, Węgry) zmierzające do jego decentralizacji i dostosowania do nowych podziałów administracyjnych (np. Polska, Rosja). W drugiej dekadzie transformacji zmiany w obszarze edukacji miały charakter zarówno zmian w strukturze systemu edukacji oraz programów kształcenia (m.in. Polska - 1999, Rumunia - 2003, Bułgaria - 2007), jak i wprowadzania mechanizmów zewnętrznej kontroli jakości i certyfikowania wiedzy uczniów (min. Bułgaria, Łotwa, Polska, Rumunia, Węgry) czy reformy kształcenia nauczycieli. Wraz z podpisaniem w 1999 roku Deklaracji Bolońskiej rozpoczął się również w krajach europejskich intensywny proces modernizacji szkolnictwa wyższego obejmujący kształt studiów wyższych (system trzystopniowy), sposób ich finansowania, kształt ścieżki kariery akademickiej, możliwość mobilności studentów i pracowników akademickich czy wprowadzanie Krajowych Ram Kwalifikacji. Bez większych wątpliwości można skonstatować, że kształt i cele systemu oświatowego - w porównaniu do okresu sprzed transformacji ustrojowej - zostały zmienione właściwie w całości i doświadczyły swoistej rewolucji.

Oczywiście w różnych krajach zmiany te miały różne nasilenie. Posiadały jednak pewną cechę wspólną, a mianowicie przybrały właściwie postać modernizacji imitacyjnej (zob. Ziółkowski, 2000; Żuk, 2010). Jej główną cechą był proces świadomego bądź nieświadomego powielania rozwiązań instytucjonalno-prawnych obecnych w krajach anglosaskich. Ogólną specyfiką tego procesu jest to, że przejście od społeczeństw komunistycznych do demokratycznych i rynkowych, mające swój indywidualny charakter w każdym z porównywanych krajów, tworzy jednakowoż szczególne „łło” socjalizacyjne młodego pokolenia, w znacznej mierze wyznaczone przez „zachodnie standardy” traktowane jako punkt orientacyjny przemian zachodzących w krajach „postkomunistycznych” (Ziółkowski, 1999, 2000). Wynikało to m.in. z faktu - jak zauważa Zdzisław Krasnodębski (2006), że po 1989 roku tak rozumiana modernizacja była naturalnym powrotem do Europy. Przyjmowano bowiem założenie, że istnieje jeden powszechnie obowiązujący model demokracji i gospodarki rynkowej (Krasnodębski, 2006).

\section{PRZEMIANY EDUKACJI POWSZECHNEJ - PODOBIEŃSTWO STRUKTUR I WSKAŹNIKÓW}

Systemy oświatowe państw postkomunistycznych wraz z transformacją ustrojową spotkał szereg znaczących zmian i reform. Ich głównym celem było zwiększenie współczynników skolaryzacyjnych w odpowiedzi na zapotrzebowanie na edukację 
i nowe kwalifikacje zgłaszane ze strony młodzieży oraz gospodarki, dopasowanie systemu edukacji do nowych wyzwań cywilizacyjnych (społecznych, kulturowych i ekonomicznych) oraz polepszenie jakości kształcenia. Wiek rozpoczęcia edukacji szkolnej wynosi 6 lat w Rumunii. Z kolei w Bułgarii, w Polsce, na Łotwie, na Węgrzech i w Rosji wynosi 7 lat (World Bank, 2015). Kłopotliwymi grupami ze względu na skolaryzację na poziomie podstawowym i ponadpodstawowym są mniejszości etniczne w krajach, w których one występują (np. Bułgaria, Rosja, Węgry czy Rumunia). W przypadku Węgier zwraca się uwagę na specyfikę edukacji mniejszości romskiej i procesy autoselekcji, które finalnie sprawiają, że trajektoria edukacyjna, a następnie zawodowa tej grupy młodzieży prowadzi ją do społecznego wykluczenia (Kertesi, Kezdi, 2011). Z kolei w Bułgarii aż 20,9\% młodzieży romskiej w wieku 15-29 lat jest analfabetami (illiterate) lub nie ukończyło żadnego formalnego poziomu wykształcenia, a jedynie $0,3 \%$ udało się zdobyć wyższe wykształcenie (NSI, 2011).

Pierwszym celem systematycznie wprowadzanych zmian było wydłużanie obowiązku szkolnego dzieci (do 15-18 roku życia) i w konsekwencji wydłużenie czasu trwania edukacji obowiązkowej (duration of compulsory education). Ta jednak jest znacząco różna i w zależności od kraju wynosi od 8 do 12 lat. Obowiązek szkolny najkrótszy jest na Węgrzech, gdzie wynosi 8 lat i w Rosji - 9 lat, w Rumunii wynosi - 10 lat. Najdłużej edukacja obowiązkowa trwa w Bułgarii, na Łotwie i w Polsce - 11 lat (World Bank, 2015).

Drugim było zwiększenie współczynników skolaryzacyjnych na wszystkich szczeblach edukacji. Z danych Banku Światowego wynika, że naukę zarówno w szkole podstawowej (primary), jak i ponadpodstawowej (secondary) rozpoczynają właściwie wszystkie dzieci w analizowanych krajach. Poza systemem edukacji pozostaje niewielki odsetek uczniów - najwyższy na Węgrzech (3,9\%) oraz w Bułgarii (3,4\%). Wskaźniki w tym obszarze pomiędzy 1995 a 2013 rokiem poprawiły się nawet kilkukrotnie we wszystkich krajach (zob. tabela 1).

We wszystkich krajach współczynniki skolaryzacyjne w grupie wiekowej odpowiadającej edukacji ponadgimnazjalnej (czyli w wieku 15-19 lat) są na bardzo wysokim poziomie sięgającym nawet $90 \%$, a okres potransformacyjny cechował znaczący wzrost tych wskaźników (w latach 1995-2013 - od 12-23 pp.) będących konsekwencją wysokich aspiracji edukacyjnych młodzieży oraz zwiększenia nakładów na edukację (zob. tabela 2).

Specyfikę krajową szkolnictwa ponadgimnazjalnego widać w znaczących różnicach jeżeli chodzi o profile kształcenia. Szkolnictwo ponadgimnazjalne najmniej „uzawodowione” jest na Węgrzech, gdzie aż 74\% uczniów podejmuje naukę w szkolnictwie ponadgimnazjalnym w ramach profilu mającego charakter 
ogólny, oraz na Łotwie - 62\%. Najmniejszy odsetek młodzieży uczęszczających do klas o profilu ogólnym jest w Polsce - jedynie 47\% oraz w Rumunii - 44\% (zob. tabela 3).

Tabela 1. Dzieci poza systemem oświatowym (odsetek dzieci w wieku szkolnym)

\begin{tabular}{lccc}
\hline Kraj & $\mathbf{1 9 9 5}$ & $\mathbf{2 0 0 5}$ & $\mathbf{2 0 1 3}$ \\
\hline Bułgaria & - & 6,2 & 3,4 \\
\hline Węgry & 9,5 & 3,7 & 3,9 \\
\hline Łotwa & - & - & 1,5 \\
\hline Polska & - & 5,1 & 2,9 \\
\hline Rumunia & 12,3 & 2,2 & - \\
\hline Rosja & 6,7 & - & 2,5 \\
\hline
\end{tabular}

Dzieci poza systemem oświatowym stanowią odsetek dzieci w wieku edukacji podstawowej, które nie uczęszczają do szkoły podstawowej lub średniej. Dzieci w wieku odpowiadającemu edukacji podstawowej, które uczęszczają do przedszkola traktowane są jako pozostające poza systemem edukacyjnym.

Źródło: World Bank. World Development Indicators.

Tabela 2. Wskaźnik skolaryzacji w grupie wiekowej 15-19 [\%]

\begin{tabular}{cccc}
\hline Kraj & $\mathbf{1 9 9 5}$ & $\mathbf{2 0 0 5}$ & $\mathbf{2 0 1 3}$ \\
\hline Węgry & 64 & 87 & 87 \\
\hline Łotwa & - & - & 94 \\
\hline Polska & 78 & 92 & 90 \\
\hline Rosja & $71^{*}$ & 74 & 84 \\
\hline
\end{tabular}

Uczniowie kształcący się w trybie stacjonarnym i niestacjonarnym, zarówno w instytucjach publicznych, jak i prywatnych.

*2000

Źródło: OECD, 2010, 2015.

Tabela 3. Odsetek uczniów szkół ponadgimnazjalnych (grupa wiekowa 15-19), z podziałem na profil kształcenia (2013)

\begin{tabular}{lccccc}
\hline Profil kształcenia & Bułgaria & Węgry & Lotwa & Polska & Rumunia* $^{*}$ \\
\hline Ogólny & 48 & 74 & 62 & 47 & 44 \\
\hline Zawodowy & 52 & 26 & 38 & 53 & 56 \\
\hline
\end{tabular}

* INS, Bukareszt, 2014.

Źródło: OECD (2015), s. 317. 
Trudno wskazać jakąś wyraźną tendencję w powyższych wskaźnikach. Różnica pomiędzy Węgrami a Polską jest znacząca i wynosi aż 27 pp. W Polsce kształcenie zawodowe od zawsze było bardzo popularne i uczniowie tego typu szkół (zarówno techników, liceów zawodowych, jak i zasadniczych szkół zawodowych) stanowili do końca XX wieku grupę dominującą w strukturze oświatowej. Było to spowodowane zarówno kwestiami ideologicznymi (kształcenie klasy robotniczej), jak i społeczno-kulturowymi (dominacja wzoru mężczyzny posiadającego zawód i utrzymującego gospodarstwo domowe, niskie aspiracje edukacyjne młodzieży). Dopiero przemiany obyczajowe rozpoczęte wraz z transformacją ustrojową oraz reformy strukturalne przeprowadzone w 1999 roku i otwarcie się szkolnictwa wyższego przyczyniły się do zmiany tej tendencji i wyrównania się proporcji studentów kształcących się w szkołach ogólnokształcących i tych kształcących się w szkołach zawodowych. Według socjologów to efekt m.in. pragmatyzacji świadomości uczniów i postępującej inflacji wykształcenia ogólnego, w tym akademickiego, w czasach głębokiego niżu demograficznego (Wasielewski, 2012) a także pojawienia się nowych źródeł finansowania z UE przeznaczonych na programy kształcenia zawodowego. Podkreślić jednak należy, że głównym problemem szkolnictwa zawodowego w Polsce jest jego dwutorowość. Zasadnicze szkoły zawodowe są obszarem szczególnie zaniedbanym jeżeli chodzi o infrastrukturę i jakość kształcenia, a także są (w konsekwencji) przedmiotem negatywnej selekcji uczniów. Trafiają tam ci, którzy nie dostaną się - niezależnie od przyczyn - do szkół maturalnych. Z kolei technika są przede wszystkim pasem transmisyjnym do studiów wyższych, o czym dobitnie świadczy fakt, że jedynie co drugi spośród uczniów tego typu szkoły uzyskuje certyfikat zawodowy (zob. Oświata, 2014). Jakkolwiek oferta pod względem ilościowym jest w Polsce bogata, to wciąż nie spełnia standardów jakościowych: profile zawodowe w Polsce trącą brakiem nowoczesności i oderwaniem od rynku pracy, a pracodawcy bardzo źle oceniają kompetencje i przygotowanie zawodowe absolwentów tego typu szkół (Szafraniec, 2011, s. 98).

Powyższe wnioski potwierdzają wyniki badań Youth on move (2011), z których wynika, że atrakcyjność kształcenia zawodowego (attractiveness of vocational education and training) jest w krajach postkomunistycznych raczej słabo oceniana; odsetek pozytywnych wskazań wynosi w Polsce zaledwie - 64\%, na Węgrzech - 66\%, na Łotwie i w Bułgarii - 68\%. W przypadku młodych Polaków, Węgrów, Bułgarów i Rumunów, głównym motywem podejmowania edukacji zawodowej jest chęć zwiększenia swoich szans na znalezienie pracy. Ocena szkolnictwa zawodowego jest powiązana z jego jakością oraz udziałem przedsiębiorstw w finansowaniu i kształceniu uczniów w tego typu szkołach. Z analiz przeprowadzonych w raporcie 
Education at Glance (2015, s. 243) wynika, że Węgry i Rosja są wśród krajów, w których poziom inwestycji realizowanych przez firmy w upper secondary jest średni przy jednoczesnym średnim (6-30\%) udziale uczniów w programach typu dual system/part time VET (vocational education and trainning). Polska w obu sferach ma niski poziom.

Z ogólnymi zmianami w poziomie wskaźników skolaryzacyjnych (i aspiracji edukacyjnych) korespondują te dotyczące uczniów decydujących się na opuszczenie systemu edukacji (early school leavers). Okazuje się bowiem, że im wyższe wskaźniki skolaryzacji na poziomie szkolnictwa wyższego (i bardziej rozbudowany system kształcenia ponadgimnazjalnego), tym niższe wskaźniki dotyczące uczniów opuszczających system oświatowy. Z danych Eurostatu wynika, że najniższe wskaźniki opuszczających system edukacji w wieku 18-24 lat ma Polska - wynoszą 5,4\% i są stabilne od kilkunastu lat. Nieco wyższe są udziałem Łotwy - 8,5\%, Węgier - 11-4\% oraz Bułgarii - 12,9\%. Wysoki odsetek młodzieży opuszczających system edukacji ma Rumunia - 18,1\%. Wskaźnik ten nie uległ znaczącej zmianie pomiędzy 2005 i 2014 rokiem. Znaczący progres (czyli zmniejszenie odsetka młodzieży opuszczającej system oświatowy w wieku 18-24 lat) pomiędzy rokiem 2005 a 2014 odnotowały Bułgaria - spadek o 7,5 pp i Łotwa - spadek o 6,9 pp. (zob. tabela 4). Specyfika młodzieży wcześnie kończącej edukację polega przede wszystkim na tym, że jest grupa potencjalnie skazana na wykluczenie. Dotyczy to szczególnie tych krajów, w których problem early school leavers powiązany jest w bezpośredni sposób z mniejszościami etnicznymi.

Tabela 4. Młodzież wcześnie opuszczająca system edukacji grupa wiekowa 18-24 [\%]

\begin{tabular}{lccc}
\hline Kraj & $\mathbf{2 0 0 5}$ & $\mathbf{2 0 1 0}$ & $\mathbf{2 0 1 4}$ \\
\hline Bułgaria & 20,4 & 13,9 & 12,9 \\
\hline Węgry & 12,5 & 10,8 & 11,4 \\
\hline Łotwa & 15,4 & 12,9 & 8,5 \\
\hline Polska & 5,3 & 5,4 & 5,4 \\
\hline Rumunia & 19,6 & 19,3 & 18,1 \\
\hline
\end{tabular}

Źródło: Eurostat.

Szkoła jako instytucja właściwie we wszystkich analizowanych krajach skoncentrowana jest przede wszystkim na przekazie wiedzy i umiejętności. Ma on coraz częściej postać kształcenia weryfikowanego poprzez testy oraz porównywalne egzaminy zewnętrzne. Wychowanie - jakkolwiek wpisane zwyczajowo w misję szkoły - traktowane jest przez nią jako element uboczny, dodatkowy jej działal- 
ności. Pewnym wyjątkiem są instytucje szkolne krajów azjatyckich, w których wychowanie stanowi niemal równoważną funkcję do tej edukacyjnej. Wynika to przede wszystkim z silnych tradycji kulturowych (osadzonych w konfucjanizmie), w których szkoła i nauczyciele obdarzeni są znaczącym autorytetem i mają realny wpływ na kształtowanie postaw młodzieży. Jednym z niewielu elementów wychowawczych, które podlegają kształtowaniu w szkole jest pamięć historyczna, kształtowana jednak doraźnie w myśl prowadzonej przez aktualną władzę polityki historycznej. Jest to rysa charakterystyczna dla wszystkich systemów oświatowych analizowanych państw, szczególnie widoczna ostatnio na Węgrzech i w Polsce.

Wszystkie systemy oświatowe są skonstruowane w ten sposób, aby umożliwić przejście pełnego cyklu edukacyjnego (dotarcie do studiów wyższych) jak największej liczbie młodych ludzi. Można powiedzieć, że idea współczesnego kształcenia podporządkowana jest zdobyciu dyplomu wyższej uczelni. Filozofia taka ma oczywiście swoje konsekwencje, z jednej strony w wysokich wskaźnikach skolaryzacyjnych na poziomie szkolnictwa wyższego, z drugiej zaś w obniżeniu jakości kształcenia na wszystkich poziomach oraz w obserwowanym systematycznie od wielu lat wzroście zainteresowania młodzieży profilami kształcenia zorientowanymi społecznie i humanistycznie. Związane jest to zazwyczaj ze zmianami struktury systemu oświatowego. Wydaje się, że wyjątkiem od tej reguły jest niemiecki system oświatowy, który sprawnie certyfikuje kompetencje zawodowe na niższych szczeblach edukacji. Tym samym zachowuje „bezpieczne i zdrowe” proporcje pomiędzy kształceniem zawodowym młodzieży na niższych szczeblach edukacji na potrzeby gospodarki, a kształceniem wysoko wykwalifikowanych specjalistów po studiach wyższych. Transformacja ustrojowa przyczyniła się do znaczącej liczby zmian i ingerencji w system edukacji we wszystkich państwach - począwszy od tych ustrojowych i strukturalnych, na programowych kończąc. Ich częstość oraz skala przyczyniły się w wielu krajach do rozchwiania całego systemu oświatowego oraz do utraty wiarygodności i autorytetu tej instytucji. W pierwszej dekadzie transformacji na Węgrzech sondaże wskazywały na wyraźne pogorszenie nastrojów społecznych związanych z edukacją, które utrzymały się w kolejnych latach pomimo polepszenia się sytuacji społeczno-ekonomicznej w kraju. Poziom zadowolenia z edukacji publicznej kształtuje się tam na poziomie $60 \%$ (Loboda, Lannert, Halász, 2007). Z kolei z badań realizowanych w Rumunii wynika, że 30\% młodzieży uczęszcza do szkoły z dużym lub bardzo dużym entuzjazmem, a jedynie $16 \%$ czyni to bez lub z niewielką radością. Wyraźnie częściej zadowoleni z systemu edukacji są młodzi mieszkańcy wsi - 38\% zadowolonych lub bardzo zadowolonych, aniżeli mieszkańcy miast - 29,3\% (zob. Sandu, Stoica, Umbreş, 2014, s. 69-76). Z kolei na Łotwie badacze zwracali uwagę, że młodzież, z jed- 
nej strony, ma wysokie oczekiwania wobec edukacji, z drugiej zaś, brakuje jej wytrwałości i motywacji do nauki, co skutkuje znacznymi wskaźnikami odpadu szkolnego (Youth, 2013).

\section{SZKOLNICTWO WYŻSZE - W STRONĘ UMASOWIENIA}

We wszystkich analizowanych państwach rozrost - na początku transformacji ustrojowej - systemu szkolnictwa wyższego był właściwie spontaniczny (zob. Borowicz, 2005). Bez wątpienia był to skutek splecionych nacisków społecznych, demograficznych, ekonomicznych i politycznych na systemy edukacyjne tych państw (Goastellec, 2008). W ich efekcie podjęto decyzję o wyznaczeniu określonego kierunku zmian w edukacji (imitującego systemy szkolnictwa wyższego zachodniego), nie przewidując do końca ich skali oraz społeczno-edukacyjnych konsekwencji (Dziedziczak-Foltyn, 2011). Bez wątpienia obszar szkolnictwa wyższego był tym, który zarówno w wymiarze strukturalnym, jak i organizacyjnym zmienił się najbardziej. Kluczowe zmiany związane były przede wszystkim z pluralizacją systemu szkolnictwa wyższego, jego prywatyzacją oraz otwarciem się uczelni na młodzież z grup społecznych do tej pory marginalizowanych. Równolegle następowały jednak procesy wewnętrznego różnicowania się szkolnictwa wyższego. Obok uczelni dostępnych dla wszystkich zaczęły powstawać również uczelnie elitarne (swoiste obszary społecznej ekskluzji) skupiające wyraźnie częściej młodzież o określonym pochodzeniu społecznym, np. wielkomiejską czy tą pochodzącą z klasy średniej i wyższej, zlokalizowane zazwyczaj w metropoliach i regionach o bardzo wysokim stopniu zamożności i rozwoju społeczno-gospodarczego, np. Moskwa, Warszawa, Bukareszt itp. (zob. Konstantinowski, 2012; Wasielewski, 2013).

Wyraźną korektę polityki dotyczącej szkolnictwa wyższego wprowadziły dopiero reformy „wymuszone” w krajach europejskich przez proces bolonizacji szkolnictwa wyższego (Curaj, Scott, Vlasceanu, Wilson, 2012; Boyadjieva, Ilieva-Trichkova, 2016; Epuran, Gârdan, Gârdan, Tescașiu, 2016). Jego istotą była konsolidacja Europejskiego Obszaru Szkolnictwa Wyższego poprzez szereg działań wspólnych w krajach deklarujących do niego swój akces. Najważniejszymi spośród nich wydają się być: wprowadzenie punktowego systemu rozliczania osiągnięć studentów ECTS (European Credit Transfer System), promocja mobilności studentów i pracowników naukowych, promocję kształcenia przez całe życie, wprowadzenie trójstopniowego podziału studiów (BA, MA, Ph D), współpraca uczelni w zakresie zapewniania jakości kształcenia oraz opracowanie kryteriów i metod oceny jakości 
kształcenia (systemy akredytacji, certyfikacji itp.) (European Commission, 2015). Procesy zapoczątkowane przez „deklarację bolońską” stały się wyznacznikiem nowych standardów w europejskim szkolnictwie wyższym. Adaptację swoich struktur i procedur obowiązujących w szkolnictwie wyższym podjęły wszystkie spośród analizowanych krajów. Efektem tych procesów był dynamiczny wzrost liczby szkół wyższych oraz liczby przyjmowanych przez nie studentów. We wszystkich krajach wskaźniki skolaryzacji w grupie wiekowej odpowiadającej poziomowi szkolnictwa wyższego przekraczają obecnie 50\%, a dynamika zmiany od początku transformacji ustrojowej jest nawet kilkukrotna (zob. tabela 5).

Tabela 5. Współczynnik skolaryzacji brutto, szkolnictwo wyższe [\%]

\begin{tabular}{lccccccc}
\hline Kraj & $\mathbf{1 9 9 0}$ & $\mathbf{1 9 9 5}$ & $\mathbf{2 0 0 0}$ & $\mathbf{2 0 0 5}$ & $\mathbf{2 0 1 0}$ & $\mathbf{2 0 1 3}$ & $\begin{array}{c}\text { Zmiana } \\
\mathbf{1 9 9 0 - 2 0 1 3}\end{array}$ \\
\hline Bułgaria & 26,2 & 36,5 & 44,5 & 44,3 & 58,0 & 66,5 & $+40,3$ \\
\hline Węgry & 14,7 & 22,2 & 35,9 & 65,1 & 60,4 & 57,0 & $+42,3$ \\
\hline Łotwa & 24,9 & 23,1 & 56,6 & 78,9 & 70,4 & 67,0 & $+42,1$ \\
\hline Polska & 20,4 & 31,6 & 50,5 & 63,0 & 73,2 & 71,2 & $+50,8$ \\
\hline Rumunia & 8,4 & 13,4 & 24,0 & 45,5 & 67,8 & 52,2 & $+43,8$ \\
\hline Rosja & 55,0 & 43,1 & 55,8 & 72,6 & - & 78,0 & $+23,0$ \\
\hline
\end{tabular}

Źródło: World Bank. World Development Indicators.

Skala zmian w szkolnictwie wyższym szczególnie mocno widoczna jest, gdy weźmiemy pod uwagę liczbę studentów przypadającą na 100 tysięcy mieszkańców. Najwyższy wskaźnik notuje Rosja - 5251 studentów na 100 tysięcy mieszkańców, Polska - 4927 oraz Łotwa - 4696. Najniższy wskaźnik jest udziałem Rumunii 3123, gdzie nastąpił jednak najwyższy przyrost liczby studentów na 100 tysięcy mieszkańców - 4,5 razy (zob. tabela 6).

Tabela 6. Liczba studentów ogółem przypadająca na 100000 mieszkańców

\begin{tabular}{lllllll}
\hline Kraj & $\mathbf{1 9 9 0}$ & $\mathbf{1 9 9 5}$ & $\mathbf{2 0 0 0}$ & $\mathbf{2 0 0 5}$ & $\mathbf{2 0 1 0}$ & $\mathbf{2 0 1 3}$ \\
\hline Bułgaria & 1789,6 & 2668,4 & 3266,3 & 3096,7 & 3875,7 & $3933,9 *$ \\
\hline Węgry & 971,3 & 1643,6 & 3003,4 & 4318,7 & 3883,8 & 3617,7 \\
\hline Łotwa & 1712,3 & 1621,0 & 3847,3 & 5867,7 & 5384,6 & 4695,9 \\
\hline Polska & 1324,1 & 2270,1 & 4104,2 & 5506,7 & 5570,2 & 4926,9 \\
\hline Rumunia & 700,3 & 1111,1 & 2045,5 & 3451,1 & 4924,0 & 3122,9 \\
\hline Rosja & 3523,3 & 3044,8 & 4324,6 & 6268,7 & $6518,8 * *$ & 5251,0 \\
\hline
\end{tabular}

*2014; ** 2009

Źródło: World Bank. Education Statistics - All Indicators. 
Tendencji powyższej nie przeszkodziły niekorzystne wskaźniki dotyczące terminowości kończenia studiów (completion rate) przez młodzież w europejskich krajach postkomunistycznych. Według danych OECD z 2011 roku jedynie 53\% węgierskich i 62\% polskich studentów kończyło studia w przepisowym terminie, czyli osiągało sukces edukacyjny. Jest to wartość poniżej średniej wszystkich krajów objętych badaniem (68\%). W przypadku Węgier, a szczególnie Polski wyraźnie widać już znaczące różnice płciowe na korzyść kobiet. Studentki węgierskie charakteryzuje o 8 pp wyższy wskaźnik terminowości kończenia studiów, studentki polskie aż o 26 pp (OECD, 2013, s. 62-68). Wśród przyczyn tej tendencji należy wskazać kilka elementów: cechy psychomotoryczne wzmacniane i uprawomocniane przez dominującą kulturę organizacyjną szkoły: promujące większą sumienność, rzetelność i pracowitość dziewcząt; korzystniejsze trajektorie edukacyjne (droga dziewcząt na studia poprzez licea, a chłopców również poprzez technika); nowe wzory życia i studiowania (m.in. częstsze podejmowanie pracy przez chłopców) oraz zmiany instytucjonalne w szkolnictwie wyższym sprzyjające nieklasycznym modelom studiów (łatwiejsza możliwość robienia przerwy i powracania na studia) (zob. Bowes i in., 2013; Hovdhaugen, Frølich, Aamodt, 2013; Nevala, 2011).

Tak intensywne zmiany w szkolnictwie wyższym nie byłyby możliwe, gdyby nie otwarcie się uczelni na kierunki studiów niewymagające znaczących nakładów finansowych w infrastrukturę bądź laboratoria, czyli kierunki społeczno-ekonomiczne, pedagogiczne czy humanistyczne (Social Sciences, Business and Law, Education or Humanities and Art). Ich specyfiką jest m.in. to, że relatywnie łatwo - ze względu właśnie na koszty - mogą je prowadzić uczelnie prywatne. To właśnie studenci tych kierunków (w tym również tych uczelni) stanowią niemal 60\% ogółu studiujących we wszystkich analizowanych krajach (zob. tabela 7). „Strategia” rozwoju wskaźników skolaryzacyjnych na poziomie szkolnictwa wyższego oparta głównie o kierunki społeczno-ekonomiczne miała określone konsekwencje. Z jednej strony taka polityka edukacyjna (spontanicznego rozwoju sektora prywatnego) dała możliwość podjęcia studiów przez rzeszę młodych ludzi, z drugiej zaś nie przyczyniła się do poprawy ich sytuacji na rynku pracy, często generując bezrobocie. Można zatem powiedzieć, że struktura podejmowanych przez młodzież kierunków studiów w krajach postkomunistycznych wydaje się być odzwierciedleniem stanu gospodarki (im bowiem silniejsza, tym większy odsetek osób kształcących się na kierunkach ścisłych i technicznych science and engineering, manufacturing and construction) oraz instytucji szkolnictwa wyższego (im większy segment prywatny, tym wyższy odsetek studentów nauk społecznych) w krajach przechodzących proces transformacji. Z danych Banku Światowego wynika, że pomiędzy 2000 a 2013 rokiem swoją popularność wśród 
młodzieży analizowanych państw zwiększyły właściwie wszystkie grupy kierunków za wyjątkiem wspomnianych już kierunków społeczno-ekonomicznych oraz pedagogicznych, a także rolniczych (zob. tabela 7). Zmiany obserwowane na przestrzeni ostatnich 25 lat wskazują na wyrównywanie się proporcji studiujących na poszczególnych kierunkach. Nadmienić jednak trzeba, że to w równym stopniu efekt działań celowych prowadzonych przez państwo (np. promocja kierunków ścisłych i technicznych), większej świadomości młodych ludzi co do rynkowej wartości poszczególnych kierunków studiów, jak i procesów demograficznych, które korygują zbyt liberalną politykę w obrębie szkolnictwa wyższego.

Kiedy spojrzymy na ogólną tendencję to okaże się, że wysokie wskaźniki skolaryzacyjne w szkolnictwie wyższym zapewniły właśnie kierunki społeczno-ekonomiczne oraz pedagogiczne. Przyjmowały one, począwszy od transformacji ustrojowej, największą liczbę nowych studentów. Ze względu na ich specyfikę oraz społeczno-kulturowe wzory karier edukacyjnych i zawodowych były to głównie kobiety. Proces ten przyczynił się do znaczącej rekonstrukcji zarówno struktury płciowej studentów, jak i ogółu osób posiadających wyższe wykształcenie, doprowadzając tym samym - jakkolwiek powoli - do zmiany sytuacji kobiet na rynku pracy.

Tabela 7. Odsetek studentów według grup kierunków studiów, rok 2000 i 2013 [\%]

\begin{tabular}{|c|c|c|c|c|c|c|c|c|c|c|}
\hline Kraj & Rok & 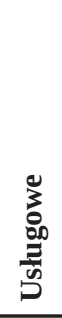 & 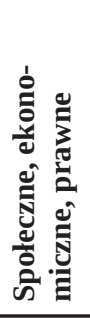 & 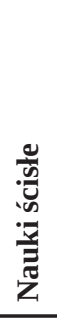 & 孞 & 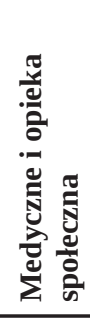 & 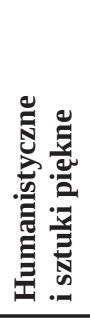 & 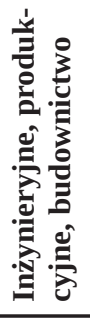 & 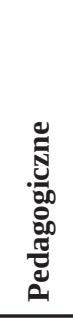 & 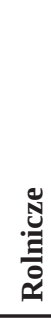 \\
\hline \multirow[t]{2}{*}{ Bułgaria } & 2013 & 8,3 & 40,2 & 5,4 & 2,5 & 8,2 & 7,6 & 18,7 & 6,8 & 2,3 \\
\hline & 2000 & 6,7 & 40,3 & 4,6 & 0,1 & 6,4 & 9,0 & 20,1 & 10,6 & 2,2 \\
\hline \multirow[t]{2}{*}{ Węgry } & 2013 & 9,4 & 38,6 & 7,8 & - & 10,0 & 9,1 & 16,0 & 6,8 & 2,6 \\
\hline & 2000 & 3,5 & 37,4 & 3,7 & 0,4 & 8,0 & 8,9 & 17,7 & 16,5 & 3,9 \\
\hline \multirow[t]{2}{*}{ Łotwa } & 2013 & 8,1 & 41,1 & 6,8 & - & 12,5 & 9,2 & 14,6 & 6,4 & 1,5 \\
\hline & 2000 & 3,3 & 46,9 & 6,3 & - & 4,2 & 7,7 & 10,2 & 19,5 & 1,8 \\
\hline \multirow[t]{2}{*}{ Polska } & 2013 & 8,7 & 35,7 & 8,3 & - & 9,2 & 8,8 & 15,7 & 12,0 & 1,7 \\
\hline & 2000 & 4,3 & 43,1 & 4,5 & 8,2 & 2,3 & 9,1 & 13,5 & 12,6 & 2,2 \\
\hline \multirow[t]{2}{*}{ Rumunia } & 2013 & 4,1 & 39,6 & 5,7 & - & 12,5 & 8,8 & 24,6 & 2,0 & 2,8 \\
\hline & 2000 & 3,2 & 41,9 & 5,6 & 4,2 & 7,3 & 10,8 & 21,9 & 1,2 & 3,9 \\
\hline
\end{tabular}

Źródło: World Bank. Education Statistics - All Indicators. 
Istotnym elementem, który w krajach europejskich wymusił zmianę polityki w obrębie szkolnictwa wyższego była (i jest) dominująca tendencja demograficzna. Transformacja ustrojowa w krajach Europy Środkowo-Wschodniej zbiegła się z nowymi trendami społeczno-demograficznymi charakterystycznymi dla rozwiniętych państw kapitalistycznych, m.in. z nowymi wzorami stylów życia zakorzenionymi w kulturze konsumpcjonizmu, nową hierarchią wartości, w której coraz większe znaczenie odgrywały praca i wykształcanie oraz nowymi wzorami dzietności, które charakteryzują niższe wskaźniki dzietności oraz późniejszy wiek zakładania rodziny. Po początkowym boomie edukacyjnym w obszarze szkolnictwa wyższego, którego efektem był dynamiczny wzrost wskaźników skolaryzacyjnych, nastąpił proces ich zahamowania, a następnie stopniowego spadku, do którego przyczynił się przede wszystkim niż demograficzny, a także proces schładzania aspiracji edukacyjnych młodzieży, będący efektem stopniowego procesu inflacji dyplomów wyższych uczelni. W znacznej mierze przyczynił się do niego również kryzys prywatnego szkolnictwa wyższego, które w zderzeniu z negatywnymi trendami demograficznymi oraz konkurencją finansowaną z budżetu państwa nie potrafi utrzymać swojej znaczącej pozycji na rynku sług edukacyjnych i traci systematycznie klientów (studentów) (zob. Kwiek, 2016). Proces ten najbardziej widoczny był/jest na Łotwie, na Węgrzech (począwszy od 2005), a także w Polsce oraz w Rosji (od 2010 roku) (zob. tabele 6 i 7).

\section{PODSUMOWANIE}

Oświata w krajach (post)komunistycznych jest jednym z tych obszarów, który w ostatnim ćwierćwieczu zmieniał się szczególnie dynamicznie. Transformacji podlegały zarówno struktury organizacyjne (m.in. struktura systemu oświatowego, sieć szkół, mechanizmy finansowania czy system ewaluacji), jak i postawy młodzieży wobec edukacj, (m.in. znacząco wzrosły aspiracje edukacyjne i poziom wykształcenia), a edukacja zaczęła być postrzegana jako istotny kapitał, w który warto inwestować. Bez wątpienia zmiany w edukacji przybrały postać modernizacji imitacyjnej - poprzez proces powielania rozwiązań instytucjonalno-prawnych obecnych w krajach anglosaskich. Proces ten, z jednej strony, przyniósł wiele pozytywnych rozwiązań opartych na dobrych i sprawdzonych wzorcach, w które wpisane zostały tak uniwersalne dzisiaj zapisy dotyczące m.in. kształtu struktury edukacyjnej, autonomii wyższych uczelni, mechanizmów finansowania czy całego procesu bolońskiego. Z drugiej jednak strony, nie uchronił on krajów transformujących się przed szeregiem błędów czy niedopatrzeń, mających swoje źródła 
zarówno w ślepym naśladownictwie, jak i w braku refleksji nad konsekwencjami wprowadzanych zmian w określonym, często innym kontekście społeczno-kulturowym. Zmiany w edukacji - często wprowadzane chaotycznie - przyniosły bądź ujawniły szereg problemów i zaniedbań wymagających korekty prowadzonej dotychczas polityki edukacyjnej. Dotyczą one zarówno jakości edukacji na wszystkich poziomach kształcenia, wciąż obecne społeczne nierówności w edukacji (np. Bułgaria, Polska), słaby związek między edukacją a rynkiem pracy, nieskuteczne mechanizmy integrowania mniejszości etnicznych w szkole (w krajach, w których stanowią one istotny odsetek, np. w Bułgarii, Rumunii czy na Węgrzech).

Bez wątpienia skala zmian, jakie dokonały się w obszarze edukacji świadczy również o skali wyzwań i zagrożeń wynikających z procesów modernizacji gospodarki, przemian społeczno-kulturowych i trendów globalnych. Zmiana miała w końcu charakter właściwie rewolucyjny. I jakkolwiek byśmy ją oceniali po upływie ćwierćwiecza, to przyniosła wiele nowych wyzwań i problemów, z którymi zmierzyć się muszą właściwie wszystkie kraje podlegające transformacji ustrojowej. W obszarze szeroko rozumianej edukacji kluczowe wydają się te związane z kryzysem demograficznym (w różnych krajach obecnym w różnym stopniu); procesami społecznej ruchliwości (zarówno wewnętrznej - głównie na osi wieś-miasto, jak i zewnętrznej - migracje zagraniczne); permanentnym niedofinansowaniem edukacji, co było i jest sprzeczne z podstawowymi założeniami wszelkich strategii rozwoju społecznego oraz coraz częstszym postrzeganiem edukacji jako wartości rynkowej, a nie społecznej (zarówno przez jednostki, jak i instytucje publiczne). Są to bez wątpienia zadania na przyszłość, i to tą najbliższą...

\section{Bibliografia:}

Antonowicz, D. (2015). Między siłą globalnych procesów a lokalną tradycją. Polskie szkolnictwo wyższe w dobie przemian. Toruń: Wydawnictwo Naukowe UMK.

Aslund, A. (2010). Jak budowano kapitalizm? Transformacja Europy Środkowej i Wschodniej, Rosji i Azji Środkowej. Warszawa: Wydawnictwo FOR.

Bauman, Z. (1998). Globalization: The Human Consequences. New York: Columbia University Press.

Becker, G.S. (1964). Human Capital. A Theoretical and Empirical Analysis with Special Reference to Education. Chicago: University of Chicago Press.

Behrman, J.R., Stacey, N. (red.) (1997). The Social Benefits of Education. Ann Arbor: The University of Michigan Press.

Berryman, S. (2000). Hidden challenges to education systems in transition economies. A World Free of Poverty series. Washington, D.C.: The World Bank. 
Berulava, M.N. (2005). Higher Education in Russia in the Light of Market Reforms. Russian Education and Society, 47 (8), s. 6-13.

Borowicz, R. (2005). Zjawiska żywiołowe w rozwoju polskiej edukacji. W: M. Dziemianowicz, B. Dorota Gołębniak, R. Kwaśnica (red.), Przetrwanie i rozwój jako niezbywalne powinności wychowania (s. 74-84). Wrocław: Wydawnictwo Naukowe Dolnośląskiej Szkoły Wyższej Edukacji TWP.

Bowes, L., Thomas, L., Peck, L., Nathwani, T. (2013). International Research on the Effectiveness of Widening Participation. Bristol: HEFCE and OFFA.

Boyadjieva, P., Ilieva-Trichkova, P. (2016). Expansion of Higher Education and Graduate Employability: Data and Insights from Central and Eastern Europe. W: V. Delteil, V. Kirov (red.), Labour and Social Transformation in Central and Eastern Europe: Europeanization and Beyond (s. 207-227). New York: Routledge.

Boudon, R. (1974). Education, Opportunity, and Social Inequality: Changing Prospects in Western Society. New York: Wiley-Interscience.

Brown, P., Lauder, H. \& Ashton, D. (2008). Education, Globalization and the Future of the Knowledge Economy. European Educational Research Journal, 7 (2), s. 131-156.

Castells, M. (1996). The rise of the network society. Oxford: Blackwell.

Collins, R. (1979). The Credential society. New York: Academic Press.

Curaj A., Scott P., Vlasceanu L., Wilson, L. (red.). (2012). European higher education at the cross roads: between the Bologna Process and national reforms. Dordrecht, Heidelberg, NY: Springer.

Dore, R.P. (1976). The Diploma Disease: Education, Qualification and Development. London: George Allen \& Unwin.

Drucker, P. (1969). The age of discontinuity. Guidelines to our changing society. New York: Harper \& Row.

Dziedziczak-Foltyn, A. (2011). Modernizacja społeczno-gospodarcza a szkolnictwo wyższe w Polsce w pryzmacie strategii imitacyjnej. Zeszyty Naukowe Wyższej Szkoły Administracji i Biznesu im. E. Kwiatkowskiego w Gdyni, 16, s. 32-46.

Epuran, G., Gârdan, I.P., Gârdan, D.A., Tescașiu, B. (2016). Modernisation of Higher Education in the Context of European Integration - A Comparative Analysis. Amfiteatru Economic, 18 (42), s. 351-368.

European Commission/EACEA/Eurydice (2015). The European Higher Education Area in 2015: Bologna Process Implementation Report. Luxembourg: Publications Office of the European Union.

Giddens, A. (2001). Nowoczesność i tożsamość. „Ja” i społeczeństwo w epoce późnej nowoczesności. Warszawa: PWN.

Goastellec, G. (2008). Changes in Access to Higher Education: From Worldwide Constraints to Common Patterns of Reform? W: D. Baker (red.), The Worldwide Transformation of Higher Education. International Perspectives on Education and Society, Vol. 9 (s. 1-26). UK: Emerald Group Publishing Limited.

Hadjar, A., Becker, R. (red.) (2009). Expected and Unexpected Consequences of the Educational Expansion in Europe and the US. Theoretical Approaches and empirical findings in comparative perspective. Bern - Stuttgart - Vien: Haupt.

Herbst, M., Wojciuk, A. (2014). Common Origin, Different Paths. Transformation of 
Education systems in the Czech Republic, Slovakia, Hungary and Poland. GRINCOH Working Paper Series, Paper No. 4.07.

Hovdhaugen, E., Frølich, N., Aamodt, P.O. (2013). Informing Institutional Management: institutional strategies and student retention. European Journal of Education, 48 (1), s. $165-177$.

Johnson, M.S. (1996). Western Models and Russian Realities in Postcommunist, Education Tertium comparationis, 2 (1996), s. 119-132.

Karpov, V., Lisovskaya, E. (2005). Educational Change in Time of Social Revolution: The Case of Post-Communist Russia in Comparative Perspective. W: B. Eklof, L.E. Holmes, V. Kaplan (red.), Educational Reform in Post-Soviet Russia. Legacies and Prospects, London: Frank Cass.

Kertesi, G., Kezdi, G. (2011). Roma employment in Hungary after the post-communist transition. Economics of Transition, 19 (3), s. 563-610.

Konstantinovskiy, D.L. (2012). Social inequality and access to higher education in Russia. European Journal of Education, 47 (1), s. 9-24.

Krasnodębski, Z. (2006). Modernizacja po polsku. W: J. Kloczkowski, M. Szułdrzyński (red.), Drogi do nowoczesności. Idea modernizacji w polskiej myśli politycznej, Kraków: Ośrodek Myśli Politycznej.

Kwiek, M. (2016). From Privatization (of the Expansion Era) to De-privatization (of the Contraction Era): A National Counter-Trend in a Global Context. W: S. Slaughter, B.J. Taylor (red.), Higher Education, Stratification and Workforce Development, Higher Education Dynamics 45, Springer International Publishing Switzerland. DOI: 10.100 7/978-3-319-21512-9_16.

Lewowicki, T. (red.) (2000). Edukacja międzykulturowa w Polsce i na świecie. Katowice: Wydawnictwo UŚ.

Loboda, Z., Lannert, J., Halász, G. (red.) (2007). Education in Hungary. Budapest: Hungarian Institute for Educational Research and Development.

Misztal, B. (2000). Prywatyzacja wyższego wykształcenia w Polsce. Wyzwania w świetle transformacji systemowej. W: B. Misztal (red.), Prywatyzacja szkolnictwa wyższego w Polsce. Kraków: Universitas.

Nevala, A-M., et al. (2011). Reducing early leaving from education and training in the EU. Brussels: European Parliament. Available at: http://www.europarl.europa.eu/activities/ committees/studies/download.do?language $=$ en \&file $=42311$.

NSI (2011). Bulgaria Population and Housing Census 2011, Vol. 1 Population, Book 2 Demographic and Social Characteristics.

OECD (2010). Education at a Glance 2013: OECD Indicators. OECD Publishing.

OECD (2015). Education at a Glance 2015: OECD Indicators, OECD Publishing.

Oświata i wychowanie w roku szkolnym 2014/2015. Warszawa: GUS.

Polyzoi E., Fullan M., Anchan J. (red.) (2003). Change Forces in Post-Communist Eastern Europe. Education in Transition. London, NY: Routledge Falmer.

Potulicka, E. (2012). Przemiany w analizowanych krajach na tle tendencji ogólnoeuropejskich. W: E. Potulicka, D. Wildebrandt-Wypych, C. Czech-Włodarczyk (red.), Systemy edukacji w krajach europejskich (s. 486-500). Kraków: Oficyna Wydawnicza Impuls. Sandu, D., Stoica, C.A., Umbres, R. (2014). Romanian Youth: concerns, aspirations, 
attitudes and life style. Research report by the Center for Urban and Regional Sociology - CURS for Friedrich-Ebert-Stiftung Romania (FES).

Szafraniec, K. (2011). Młodzi 2011. Warszawa: Kancelaria Prezesa Rady Ministrów.

Wasielewski, K. (2012). Zmiany poziomu aspiracji edukacyjnych młodzieży jako efekt adaptacji do nowych warunków społeczno-ekonomicznych. W: M. Zahorska (red.), Zawirowania systemu edukacji. Z perspektywy socjologicznych warsztatów badawczych (s. 72-84). Warszawa: Wydawnictwo UW.

Wasielewski, K. (2013). Młodzież wiejska na uniwersytecie - droga na studia, mechanizmy alokacji, postawy wobec kształcenia. Toruń: Wydawnictwo Naukowe UMK.

World Bank (2015). World Development Indicators. Pobrane z: http://databank.worldbank. org/data/reports.aspx?source=2\&country=\&series=SE.PRM.CMPT.ZS\&period=.

Youth on the Move (2011). Flash Eurobarometer 319b: Education and Training, Mobility, Employment and Entrepreneurship. The Gallup Organization.

Youth in Latvia 2008-2013: Activity, Mobility, Participation. Ministry of Education and Science of Republic of Latvia (2013). [Jaunieši Latvijā 2008-2013: Aktivitāte, Mobilitāte, Līdzdalība. LR Izglītības un Zinātnes ministrija. Pobrane z http://www. izm.gov.lv/images/statistika/petijumi/Jauniesi_Latvija_2008-201].

Ziółkowski, M. (1999). O imitacyjnej modernizacji społeczeństwa polskiego. W: P. Sztompka (red.) Imponderabilia wielkiej zmiany: mentalność, wartości i więzi społeczne czasów transformacji. Warszawa-Kraków: Wydaw. Naukowe PWN.

Ziółkowski, M. (2000). Przemiany interesów i wartości społeczeństwa polskiego. Teorie, tendencję, interpretacje. Poznań: Wydawnictwo Fundacji Humaniora.

Żuk, P. (2010). Modernizacja imitacyjna w warunkach społeczeństwa półperyferyjnego - refleksje socjologiczne o przemianach systemowych w Polsce. Studia i Prace Uniwersytetu Ekonomicznego w Krakowie, 12, s. 91-100. 